\title{
Recombinant Factor VIla in the Management of Surgery and Acute Bleeding Episodes in Children with Haemophilia and High-Responding Inhibitors
}

\author{
Owen P. Smith \\ National Centre for Hereditary Coagulation Disorders, The National Children's Hospital, Dublin, and \\ St. J ames's Hospital, Dublin, Ireland
}

\section{Key Words}

Children · Inhibitors · Surgery · Bleeding episodes

\begin{abstract}
The development of inhibitors to therapeutic factor concentrates in children with haemophilia A or B is a troublesome complication of factor replacement therapy. Immune tolerance protocols have been developed to eliminate the inhibitors, and these are successful in approximately $80 \%$ of children. However, acute bleeding episodes require treatment with a factor (F)VIII or FIX bypassing agent to prevent an anamnestic rise in the inhibitor level before starting immune tolerance. In addition, central venous access is necessary to help parents administer frequent, high dose factor concentrate. In view of the benefits of rFVIla seen in adults, a study has been carried out on the use of this agent as haemostatic cover in children with severe FVIII or FIX deficiency with high responding inhibitors. Information was obtained retrospectively from the National Children's Hospital, Dublin and Great Ormond Street Hospital, London. Twelve children aged 1-16 years were treated successfully with rFVIla to prevent surgical bleeding in 20 surgical procedures. Minor post-operative haematomata developed in 2 of 20 cases after regular rFVIla therapy had
\end{abstract}

been discontinued. In both cases, resolution of bleeding occurred after a short course of rFVlla. Three children experienced a total of six life- or limb-threatening bleeds. All bleeding episodes resolved with regular rFVlla treatment, although topical fibrin glue was needed in one child with a frenulum tear. The rFVIla therapy was well tolerated and there was no evidence of any treatmentrelated complications. In conclusion, rFVIla is the treatment of choice for the management of surgery and acute life- or limb-threatening bleeding in children with haemophilia and high responding inhibitors.

Copyright @2002 S. Karger AG, Basel

\section{Introduction}

Inhibitor formation is a serious complication of haemophilia therapy as it impairs the efficacy of factor replacement treatment. Patients with high titre inhibitors fail to respond to factor concentrates even if high doses of the treatment are used. Patients most at risk of inhibitor development are those with previously untreated haemophilia, usually children with severe haemophilia A. The incidence of inhibitors approaches $33 \%$ in patients with FVIII deficiency and 3\% of those with FIX deficiency [1].

\begin{tabular}{ll}
\hline KARGER & ( ) 2002 S. Karger AG, Basel \\
Fax +41613061234 & $1424-8832 / 02 / 0327-0022 \$ 18.50 / 0$ \\
$\begin{array}{l}\text { E-Mail karger@karger.ch } \\
\text { www.karger.com }\end{array}$ & $\begin{array}{l}\text { Accessible online at: } \\
\text { www.karger.com/journals/pht }\end{array}$
\end{tabular}

Dr. Owen Smith

Medical Director/Consultant Haematologist

National Centre for Hereditary Coagulation Disorders

St James's Hospital, Dublin 8 (Ireland)

Tel. +353 1453 7941, Fax +3531410 3475, E-Mail osmith@stjames.ie 
Several publications have shown that immune tolerance therapy (ITT) can ablate the inhibitors in $80 \%$ of children who develop them [2-5]. Immune tolerance is more likely to succeed if the patient has an inhibitor titre less than 10 Bethesda Units (BU). However, acute bleeding episodes continue to require adequate haemostatic cover with a FVIII- or FIX-bypassing agent to prevent an anamnestic rise in the inhibitor level before starting ITT. In addition, young children require the insertion of a central venous access catheter, again with haemostatic cover, to help parents administer frequent high dose factor concentrate and acute treatment. The provision of this haemostatic cover can be achieved with rFVIIa. To date, the use of rFVIIa has been predominantly in adults with severe FVIII-deficiency and inhibitors who are undergoing surgery [6]. The agent has also become established as the treatment of choice for acute life-threatening bleeding episodes in adult haemophilia patients with inhibitors.

In the light of the experience with rFVIIa in adults, there has been much interest over the past few years in the use of this agent in paediatric patients who have severe FVIII-or FIX-deficiency with inhibitors. A study has therefore been carried out to investigate the use of rFVIIa in the management of surgery and acute bleeding episodes in children with haemophilia and high responding inhibitors [7].

\section{Study Design}

The study was a retrospective chart review by the National Children's Hospital in Dublin and the Great Ormond Street Hospital for Children in London. The review included children with haemophilia and inhibitors who received rFVIIa between December 1995 and December 2000. During this time, 12 children received rFVIIa for the prevention of bleeding during a total of 20 surgical procedures (table 1). Additionally, rFVIIa treatment was given to 3 children among whom there were 6 acute life- or limb-threatening bleeding episodes.

\section{Regimen}

For the surgical cover, the dose of rFVIIa used in the Dublin centre was $90 \mu \mathrm{g} / \mathrm{kg}$ every $2 \mathrm{~h}$ during the first $24 \mathrm{~h}$ and then every $4 \mathrm{~h}$ during the following $24 \mathrm{~h}$. At Great Ormond Street, the dose used for surgical cover was $90 \mu \mathrm{g} / \mathrm{kg}$ 2-hourly for the first day, 3-hourly for the second day and 4-hourly for the third day. The acute bleeding episodes were treated with a dose of rFVIIa of $90 \mu \mathrm{g} / \mathrm{kg}$ every $2-4 \mathrm{~h}$ until the bleeding stopped. All these patients
Table 1. Study design for the two-centre investigation of the use of rFVIIa in the management of surgery and acute bleeds in children with haemophilia and inhibitors

- rFVIIa usage in children with sFVIII/IX and inhibitors Dec 1995 to Dec 2000.

- Retrospective via chart review

- rFVIIa dosage used for acute bleeds: - $90 \mu \mathrm{g} / \mathrm{kg} 2-4 \mathrm{~h}$ until bleeding stopped

(TxA $15 \mathrm{mg} / \mathrm{kg}$, topicalfibrin glue in 1 patient)

- rFVIIa dosage for surgical cover:

$-90 \mu \mathrm{g} / \mathrm{kg}, 2 \mathrm{~h} \times 24 \mathrm{~h}, 4 \mathrm{~h} \times 24 \mathrm{~h}(\mathrm{NCH})$

$-90 \mu \mathrm{g} / \mathrm{kg}, 2 \mathrm{~h} \times 24 \mathrm{~h}, 3 \mathrm{~h} \times 24 \mathrm{~h}, 4 \mathrm{~h} \times 24 \mathrm{~h}(\mathrm{GOS})$

(TxA $15 \mathrm{mg} / \mathrm{kg}$ i.v. or p.o. $\times 1$ week)

- Efficacy - clinical assessment/shortening of PT

Table 2. Patient characteristics of participants in the London/Dublin study

\begin{tabular}{lc}
\hline Median age, years & 2.5 \\
Range & $1-16$ \\
FVIII & 12 \\
FIX & 1 \\
Max. historical BU & \\
$\quad$ Median & 120 \\
$\quad$ Range & $2-712$ \\
BU at time of rFVIIa & \\
$\quad$ Median & 12 \\
$\quad$ Range & $<1-100$ \\
\hline
\end{tabular}

also received tranexamic acid in a dose of $15 \mathrm{mg} / \mathrm{kg}$ either intravenously or orally for 1 week.

Efficacy was measured by clinical assessment of haemostasis. Shortening of the prothrombin time was also measured.

\section{Patient Characteristics}

The patients in this study had a median age of 2.5 years, ranging from 1 to 16 years (table 2). Of the patients, 12 were FVIII-deficient and one was FIX-deficient. The patients' records showed that their median maximum historical inhibitor titre was $120 \mathrm{BU}$ with a range of 2-712 $\mathrm{BU}$. At the time of rFVIIa treatment, the median inhibitor level was $12 \mathrm{BU}$ with a range of $1-100 \mathrm{BU}$.

\section{Surgery}

The operations included 19 procedures for insertion or removal of a central venous access device (CVAD) and 
Table 3. Surgical procedures

\begin{tabular}{ll}
\hline Number of patients & 12 \\
Total number of procedures & 20 \\
CVAD insertion or removal & 19 \\
Multiple dental extractions & 1 \\
Duration of cover, h & \\
$\quad$ Median & 48 \\
$\quad$ Range & $12-72$ \\
Total dose rFVIIa, mg & \\
$\quad$ Median & 43.2 \\
$\quad$ Range & $19.2-124.8$ \\
\hline
\end{tabular}

Table 4. Acute life-threatening bleeding episodes

\begin{tabular}{lc}
\hline Number of patients & 3 \\
Total number of bleeds & 6 \\
Mouth bleed & 3 \\
Port bleed & 2 \\
Forearm bleed/neuro \$ms & 1 \\
Duration of cover, h & \\
$\quad$ Median & 20 \\
$\quad$ Range & $4-96$ \\
Total dose rFVIIa, mg & \\
$\quad$ Median & 43.2 \\
$\quad$ Range & $2.4-46.8$ \\
\hline
\end{tabular}

one multiple dental extraction (table 3). The median duration of surgical cover with rFVIIa was $48 \mathrm{~h}$, ranging from 12-72 $\mathrm{h}$. The median total dose of rFVIIa for surgery was $43 \mathrm{mg}$ with a range of $19-125 \mathrm{mg}$.

All the surgical patients were treated successfully with rFVIIa. Two of the patients had minor bleeding 3 days after insertion of their CVAD, at which time both had discontinued their rFVIIa treatment. Re-treatment with 2-3 doses of rFVIIa resolved the bleeding.

\section{Acute Bleeding}

The 6 acute bleeds that occurred in 3 patients included mouth bleeds in 3 patients and port bleeds in 2 patients following insertion of a needle. One child had a forearm bleed with neurological symptoms. Three of the 6 bleeding episodes were associated with significant anaemia, haemoglobin levels dropping below $8 \mathrm{~g} / \mathrm{dl}$. Transfusion of red blood cells was required in 2 of the bleeding episodes.
Patients in the acute bleed group received rFVIIa treatment over a median of $20 \mathrm{~h}$, ranging from 4-96 h (table 4). The median total dose of rFVIIa in these patients was $43 \mathrm{mg}$, ranging from $2-47 \mathrm{mg}$. All the bleeding episodes resolved with rFVIIa treatment, except one case involving a frenulum tear, which was brought under control by application of topical fibrin glue.

\section{Prothrombin Time}

Prothrombin time (PT) was measured in all 20 surgical procedures and in 1 of the patients with acute bleeds. In all 21 occasions, the PT shortened to the lower limit of normal following rFVIIa treatment. It was assumed this confirmed that a haemostatic level of FVII:C had been reached.

\section{Side Effects}

Treatment with rFVIIa was well tolerated. No treatment-related complications were seen in any of these surgical or acute bleed cases. There was no evidence of systemic activation of coagulation as indicated by activation markers including a D-Dimer.

\section{Conclusion}

We concluded from this series that rFVIIa was shown to be extremely effective and reliable in the management of acute bleeding episodes and in the prevention of surgical bleeding in children with FVIII- or FIX-deficiency with inhibitors.

Further research is required to determine the optimum therapeutic dose of rFVIIa in the paediatric setting. As the half-life of rFVIIa in children is only half that in adults, it could be that a lower bolus dose of rFVIIa would be effective. In assessing the best dose regimen, it may be necessary to examine more closely the kinetics of FVII:C in haemophiliac children with inhibitors during rFVIIa treatment. In this study, we noted that increasing the dosing intervals to 4-hourly was associated with a drop in the FVII:C levels which no longer exceeded the threshold believed to be necessary for haemostasis. 


\section{References}

1 Hay CR, Baglin TP, Collins PW, Hill FG, Keeling DM: The diagnosis and management of factor VIII and factor IX inhibitors: A guideline from the UK Haemophilia Doctors' Organization (UKHCDO). Br J Haematol 2000; 111:7890.

2 Kreuz W, Ehrenforth S, Funk M, Auerswald D, Mentzer J, Joseph-Steiner J, Beeg T, Klarmann D, Scharrer I, Kornhuber B: Immune tolerance therapy in paediatric haemopiliacs with factor VIII inhibitors: 14 years follow-up. Haemophilia 1995;1:24-32.
3 Mauser-Bunschoten EP, Nieuwenhuis HK, Roosendaal G, van den Berg HM: Low-dose immune tolerance induction in hemophilia A patients with inhibitors blood 1995;86:983988

4 Di Michele DM: Immune Tolerance: A synopsis of the international experience. Haemophilia 1998;4:568-573.

5 Brackmann HH, Effenberger E, Hess L, Schwaab R, Oldenburg J: NovoSeven ${ }^{\circledR}$ in immune tolerance therapy. Blood Coagul Fibrin 2000;11(suppl 1):39-44.
6 Lusher J, Ingersley J, Roberts H, Hedner U: Clinical experience with recombinant factor VIIa. Blood Coagul Fibrin 1998;9:119-128.

7 O'Connell N, McMahon C, Smith J, Khair K, Hann I, Liesher R, Smith OP: Recombinant factor VIIa in the management of surgery and acute bleeding episodes in children with haemophilia and high responding inhibitors. $\mathrm{Br} \mathrm{J}$ Haematol 2001;116:632-635.
rFVIIa in Children with Acute Bleeds and Surgery 